\title{
Rumen-protected methionine during the peripartal period in dairy cows and its effects on abundance of major species of ruminal bacteria
}

Mohamed K. Abdelmegeid ${ }^{1,2}$, Ahmed A. Elolimy ${ }^{1}$, Zheng Zhou ${ }^{3}$, Vincenzo Lopreiato ${ }^{1,4}$, Joshua C. McCann ${ }^{1}$ and Juan J. Loor ${ }^{1,5^{*}}$ (D)

\begin{abstract}
Background: Extensive degradation of amino acids in the rumen via microbial deamination decreases the postruminal availability of dietary indispensable amino acids. Together with the normal decrease in voluntary dry matter intake (DMI) around parturition in dairy cows, microbial metabolism contributes to a markedly negative balance of indispensable amino acids, including methionine which may be the first-limiting for milk production. The main objective of the current study was to profile changes in major bacterial species with key functions in cellulose and hemicellulose digestion, xylan breakdown, proteolytic action, propionic acid production, lactate utilization and ruminal biohydrogenation in cows supplemented with rumen-protected Methionine (SM; Smartamine M, Adisseo NA, Alpharetta, GA, USA) from -23 through 30 d relative to parturition. Because 90\% of the methionine in SM bypasses the rumen, $\sim 10 \%$ of the methionine is released into the rumen and can be utilized by microbes.

Results: As expected, there was an increase in overall DMl after parturition (Day, $P<0.05$ ) during which cows consumed on average $19.6 \mathrm{~kg} / \mathrm{d}$ versus $13.9 \mathrm{~kg} / \mathrm{d}$ in the prepartum period. The postpartum diet contained greater concentrations of lipid and highly-fermentable carbohydrate from corn grain, which likely explains the increases in the relative abundance of Anaerovibrio lipolytica, Megasphaera elsdenii, Prevotella bryantii, Selenomonas ruminantium, Streptococcus bovis, and Succinimonas amylolytica. Despite similar DMI prepartum, cows fed SM had greater (Treatment $\times$ Day, $P<0.05)$ abundance prepartum of Fibrobacter succinogenes, Succinimonas amylolytica, and Succinivibrio dextrinosolvens. However, the greater DMI in cows fed SM after parturition (19.6 kg/d versus $13.9 \mathrm{~kg} / \mathrm{d}$ ) was associated with lower abundance of Fibrobacter succinogenes $\left(2.13 \times 10^{-3}\right.$ versus $\left.2.25 \times 10^{-4}\right)$ and Selenomonas ruminantium $\left(2.98 \times 10^{-1}\right.$ versus $\left.4.10 \times 10^{-1}\right)$. A lower abundance (Day, $P<0.05$ ) was detected on $\mathrm{d} 20$ compared with $d-10$ for Fibrobacter succinogenes and Succinivibrio dextrinosolvens. The relative abundance of Butyrivibrio proteoclasticus and Eubacterium ruminantium was stable across treatment and time.

(Continued on next page)
\end{abstract}

\footnotetext{
* Correspondence: jloor@illinois.edu

'Department of Animal Sciences, Mammalian NutriPhysioGenomics,

University of Illinois, Urbana, IL 61801, USA

${ }^{5}$ Division of Nutritional Sciences, Illinois Informatics Institute, University of

Illinois, Urbana, IL, USA

Full list of author information is available at the end of the article
} 
(Continued from previous page)

Conclusions: In diets with proper balance of rumen-degradable protein and fermentable carbohydrate, the small fraction of Methionine released from the rumen-protected supplement did not seem to compromise growth of major bacterial species in the rumen. In fact, it had a positive effect on 3 major species prepartum when DMI was similar between groups. Because the actual requirements of Methionine (and Lysine, for example) by the cow during the transition period are unknown, it appears warranted to study the rumen microbiome as it relates to supply of rumen-protected amino acids.

Keywords: Microbiome, Rumen microbes, Transition cow

\section{Background}

Extensive degradation of amino acids in the rumen [1] via microbial deamination $[2,3]$ substantially lowers the postruminal availability of dietary indispensable amino acids (IAA). Together with the normal decrease in voluntary dry matter intake (DMI) around parturition in dairy cows, microbial metabolism contributes to a markedly negative balance of IAA, including methionine which often is the first-limiting amino acid [4]. Therefore, the importance of enhancing the delivery methionine to the small intestine through "rumen by-pass" technologies has been underscored since the early 1960's [5]. The physiologic impact of supplementing dairy diets with rumen-protected methionine (RPM) at lactation stages where needs are the greatest has received close attention worldwide, i.e. improving the overall health, metabolism, and production performance in dairy cows [6-9]. With the advances in methionine protection technology, a large proportion of protected methionine escapes ruminal degradation but a small fraction of methionine is still released into the rumen and may change the community composition of the rumen microbiota and their metabolism.

During the peripartal period, dairy cow diets move from higher-forage content before calving to higher-concentrate diets postpartum to provide the rumen microbial communities with more readily-available energy. As a result, microbial composition changes in favor of generating more volatile fatty acids (VFA) and microbial protein to serve as a fuel and amino acid sources, respectively, for body tissues and milk synthesis [10-12]. Therefore, nutritional management plays a key role in shaping the microbial ecosystem in the rumen $[13,14]$. Despite the continued focus on nutritional management of peripartal cows, little is known about the response of rumen microbes to methionine supplementation. For example, Salsbury et al. [15] and Gil et al. [3] were among the first to observe that unprotected supplemental methionine enhanced ruminal bacteria growth rate and protein synthesis in vitro.

Although there is growing evidence that RPM enhances overall dairy cow health and productivity, whether ruminal bacteria composition changes in response to RPM supplementation remains unknown. Therefore, the objective of the current study was to profile changes in major bacterial species with key functions in cellulose and hemicellulose digestion, xylan breakdown, proteolytic action, propionic acid production, lactate utilization and ruminal biohydrogenation in cows supplemented with RPM (Smartamine $\mathrm{M}$, Adisseo NA, Alpharetta, GA) from -23 through $30 \mathrm{~d}$ around parturition. Smartamine $\mathrm{M}$ is designed to release over $90 \%$ of the methionine along the small intestine. Thus, the remaining $10 \%$ of the methionine is released into the rumen and can be utilized by microbes. Hence, the hypothesis was that the liberated methionine portion into the rumen following dietary RPM supplementation could affect the composition of major ruminal bacteria around calving.

\section{Methods}

Animal handling and all procedures of this study received approval from the Institutional Animal Care and Use Committee of the University of Illinois under protocol no. 13023. In total, a subset of 20 multiparous cows from a larger study [16] were randomly selected for ruminal fluid sampling. These cows were either fed a control diet without RPM (CON) or CON plus RPM supplementation (SM) at a rate of $0.08 \%$ of DMI (Smartamine M, Adisseo NA, Alpharetta, GA). Dosage of RPM was based on previous work from our research group [17]. At the start of the experimental feeding phase, none of the cows enrolled had received any type of RPM. All cows received a far-off diet (Table 1) as total mixed ration (TMR) from -50 to $-22 \mathrm{~d}$ before expected calving date $(1.40 \mathrm{Mcal} / \mathrm{kg}$ of DM, $10.2 \%$ rumen-degradable protein, and $4.1 \%$ rumenundegradable protein), a close-up diet from $-21 \mathrm{~d}$ to the expected calving date $(1.52 \mathrm{Mcal} / \mathrm{kg}$ of DM, $9.1 \%$ rumendegradable protein, and $5.4 \%$ rumen-undegradable protein) and a lactation diet after calving through $30 \mathrm{~d}$ postpartum $(1.71 \mathrm{Mcal} / \mathrm{kg}$ of DM, $9.7 \%$ rumen-degradable protein, and $7.5 \%$ rumen-undegradable protein). The TMR was delivered once daily $(0600 \mathrm{~h})$ using an electronic recognition feeding system for each cow (American Calan, Northwood, NH) before calving or in open individual mangers during lactation. The DM content of the TMR for the close-up and lactation diets was measured weekly for estimation of daily TMR dry matter offered. The required amount of RPM was calculated daily for each 
Table 1 Ingredients and chemical composition of experimental diets

\begin{tabular}{|c|c|c|c|}
\hline \multirow[b]{2}{*}{$\begin{array}{l}\text { Ingredient, } \\
\% \text { of DM }\end{array}$} & \multicolumn{3}{|l|}{ Diet } \\
\hline & Far-off & Close-up & Lactation \\
\hline Alfalfa silage & 12.00 & 8.34 & 5.07 \\
\hline Alfalfa hay & - & 4.29 & 2.98 \\
\hline Corn silage & 33.00 & 36.40 & 33.41 \\
\hline Wheat straw & 36.00 & 15.63 & 2.98 \\
\hline Cottonseed & - & - & 3.58 \\
\hline $\begin{array}{l}\text { Wet brewers } \\
\text { grains }\end{array}$ & - & 4.29 & 9.09 \\
\hline $\begin{array}{l}\text { Ground shelled } \\
\text { corn }\end{array}$ & 4.00 & 12.86 & 23.87 \\
\hline Soy hulls & 2.00 & 4.29 & 4.18 \\
\hline $\begin{array}{l}\text { Soybean meal, } \\
48 \% \text { CP }\end{array}$ & 7.92 & 2.57 & 2.39 \\
\hline $\begin{array}{l}\text { Expeller soybean } \\
\text { meal }^{a}\end{array}$ & - & 2.57 & 5.97 \\
\hline Soychlor ${ }^{b}$ & 0.15 & 3.86 & - \\
\hline $\begin{array}{l}\text { Blood meal, 85\% } \\
\text { CP }\end{array}$ & 1.00 & - & - \\
\hline ProVAAI AADvantage ${ }^{c}$ & - & 0.86 & 1.50 \\
\hline Urea & 0.45 & 0.30 & 0.18 \\
\hline Rumen-inert fat ${ }^{d}$ & - & - & 1.02 \\
\hline Limestone & 1.30 & 1.29 & 1.31 \\
\hline Salt & 0.32 & 0.30 & 0.30 \\
\hline Dicalcium phosphate & 0.12 & 0.18 & 0.30 \\
\hline Magnesium oxide & 0.21 & 0.08 & 0.12 \\
\hline Magnesium sulfate & 0.91 & 0.99 & - \\
\hline Sodium bicarbonate & - & - & 0.79 \\
\hline Potassium carbonate & - & - & 0.30 \\
\hline Calcium sulfate & - & - & 0.12 \\
\hline Mineral vitamin mix & 0.20 & 0.17 & 0.18 \\
\hline Vitamin $A^{f}$ & 0.015 & - & - \\
\hline Vitamin $D^{g}$ & 0.025 & - & - \\
\hline Vitamin $\mathrm{E}^{\mathrm{h}}$ & 0.38 & 0.39 & - \\
\hline Biotin & - & 0.35 & 0.35 \\
\hline
\end{tabular}

${ }^{a}$ SoyPLUS (West Central Soy, Ralston, IA)

${ }^{\mathrm{b}}$ By West Central Soy

'Perdue AgSolutions LLC (Ansonia, $\mathrm{OH}$ )

dEnergy Booster 100 (Milk Specialties Global, Eden Prairie, MN)

${ }^{\mathrm{e}}$ Contained a minimum of $5 \% \mathrm{Mg}, 10 \% \mathrm{~S}, 7.5 \% \mathrm{~K}, 2.0 \% \mathrm{Fe}, 3.0 \%$

$\mathrm{Zn}, 3.0 \% \mathrm{Mn}, 5,000 \mathrm{mg}$ of Cu/kg, $250 \mathrm{mg}$ of $1 / \mathrm{kg}, 40 \mathrm{mg}$ of Co/ $/ \mathrm{kg}$,

$150 \mathrm{mg}$ of Se/kg, 2,200 klU of vitamin A/kg, $660 \mathrm{kIU}$ of vitamin

$\mathrm{D}_{3} / \mathrm{kg}$, and $7,700 \mathrm{IU}$ of vitamin $\mathrm{E} / \mathrm{kg}$

${ }^{\mathrm{f} C}$ Contained $30,000 \mathrm{kIU} / \mathrm{kg}$

${ }^{9}$ Contained $5,009 \mathrm{klU} / \mathrm{kg}$

${ }^{\mathrm{h}}$ Contained $44,000 \mathrm{klU} / \mathrm{kg}$

individual cow and was top-dressed from $-21 \pm 2$ to $30 \mathrm{~d}$ relative to parturition once daily at the morning feeding using approximately $50 \mathrm{~g}$ of ground corn as carrier.
Ruminal bacteria DNA isolation and qPCR amplification of 16S rDNA genes

At $-10 \mathrm{~d}$ before expected calving date and $\mathrm{d} 20$ postpartum, ruminal fluid was sampled from each cow using a stomach tube prior to the morning feeding. The sample was filtered through three layers of cheesecloth. Mixed ruminal fluid was immediately frozen in liquid nitrogen followed by storage at $-80^{\circ} \mathrm{C}$. Total genomic DNA was isolated using the repeated bead beating method described by $\mathrm{Yu}$ and Morrison [18] for mechanical lysis of bacterial cell wall, employing the QIAamp DNA mini kit (QIAGEN) for DNA purification. The DNA quantity and quality were checked by $0.8 \%(\mathrm{wt} / \mathrm{v})$ agarose gel electrophoresis and NanoDrop spectrophotometer (ND 1000, NanoDrop Technologies, Inc., Wilmington, DE, USA) at $260 \mathrm{~nm}$. Extracted DNA was standardized to $8 \mathrm{ng} / \mu \mathrm{L}$ for $\mathrm{qPCR}$.

The primer sets selected to amplify 10 targeted rumen bacterial species are listed in Table 2 and were validated using gel electrophoresis. A total of $10 \mu \mathrm{L}$ of qPCR mixture contained $4 \mu \mathrm{L}$ sample DNA, $5 \mu \mathrm{L} 1 \times$ SYBR Green with ROX (Quanta BioSciences, Gaithersburg, MD, USA), $0.4 \mu \mathrm{L}$ each of $10 \mu \mathrm{mol} / \mathrm{L}$ forward and reverse primers, and $0.2 \mu \mathrm{L}$ DNase/RNase free water in a MicroAmp ${ }^{\text {Tx }}$ Optical 384-Well Reaction Plate (Applied Biosystems, Foster City, CA, USA). Negative controls without template DNA, standards, and samples were run on the same plate in triplicate. The qPCR reactions were performed with the ABI Prism 7900HT Fast Real-Time PCR System (Applied Biosystems, Foster City, CA, USA) using the following program: initial denaturation at $95{ }^{\circ} \mathrm{C}$ for $5 \mathrm{~min}$, followed by 40 cycles of $1 \mathrm{~s}$ at $95^{\circ} \mathrm{C}$ and $30 \mathrm{~s}$ annealing at $60{ }^{\circ} \mathrm{C}$, except for eubacterial primer 3 that required an annealing temperature of $56^{\circ} \mathrm{C}$. A dissociation stage was performed to determine the specificity of the amplification. Relative abundance of bacterial species was calculated using the geometric mean of two universal primers $[19,20]$ with the efficiency-corrected $\Delta^{-\mathrm{CT}}$ method [21]. Thus, the abundance of each target bacteria was determined relative to the overall abundance of the total bacteria as measured with the universal primers.

\section{Statistical analysis}

Dry matter intake and relative abundance of bacteria were analyzed using the MIXED procedure of SAS 9.3 (SAS Inst. Inc., Cary, NC, USA). The fixed effects in the model were Day, Treatment, and the interaction of Day $\times$ Treatment. The random effect was cow within treatment.

\section{Results}

Dry matter intake

As expected, there was an increase in overall DMI after parturition (Day, $P<0.05$ ) during which cows consumed on average $19.6 \mathrm{~kg} / \mathrm{d}$ versus $13.9 \mathrm{~kg} / \mathrm{d}$ in the prepartum period. The overall effect of treatment $(P<0.05)$ was due 
Table 2 Species-specific primers for the quantification of selected rumen bacterial populations using a real-time qPCR assay

\begin{tabular}{|c|c|c|c|}
\hline $\begin{array}{l}\text { Target bacterial } \\
\text { species }\end{array}$ & & $\begin{array}{l}\text { Primer sequence } \\
\left(5^{\prime} \rightarrow 3^{\prime}\right)\end{array}$ & Reference \\
\hline \multirow[t]{2}{*}{ Anaerovibrio lipolytica } & $\mathrm{F}^{\mathrm{a}}$ & GAAATGGATTCTAGTGGCAAACG & [12] \\
\hline & $\mathrm{R}: \mathrm{b}$ & ACATCGGTCATGCGACCAA & \\
\hline \multirow[t]{2}{*}{ Butyrivibrio proteoclasticus } & $\mathrm{F}:$ & GGGCTTGCTTTGGAAACTGTT & [12] \\
\hline & $\mathrm{R}:$ & CCCACCGATGTTCCTCCTAA & \\
\hline \multirow[t]{2}{*}{ Eubacterium ruminantium } & $\mathrm{F}:$ & CTCCCGAGACTGAGGAAGCTTG & [37] \\
\hline & $\mathrm{R}:$ & GTCCATCTCACACCACCGGA & \\
\hline \multirow[t]{2}{*}{ Fibrobacter succinogenes } & $\mathrm{F}:$ & GCGGGTAGCAAACAGGATTAGA & [37] \\
\hline & $\mathrm{R}:$ & CCCCCGGACACCCAGTAT & \\
\hline \multirow[t]{2}{*}{ Megaspheara elsdenii } & $\mathrm{F}:$ & AGATGGGGACAACAGCTGGA & [37] \\
\hline & $\mathrm{R}:$ & CGAAAGCTCCGAAGAGCCT & \\
\hline \multirow[t]{2}{*}{ Prevotella bryantii } & $\mathrm{F}:$ & AGCGCAGGCCGTTTGG & [37] \\
\hline & $\mathrm{R}:$ & GCTTCCTGTGCACTCAAGTCTGAC & \\
\hline \multirow[t]{2}{*}{ Selenomonas ruminantium } & $\mathrm{F}:$ & CAATAAGCATTCCGCCTGGG & [37] \\
\hline & $\mathrm{R}:$ & TTCACTCAATGTCAAGCCCTGG & \\
\hline \multirow[t]{2}{*}{ Succinimonas amylolytica } & $\mathrm{F}:$ & CGTTGGGCGGTCATTTGAAAC & [29] \\
\hline & $\mathrm{R}:$ & CCTGAGCGTCAGTTACTATCCAGA & \\
\hline \multirow[t]{2}{*}{ Streptococcus bovis } & $\mathrm{F}:$ & TTCCTAGAGATAGGAAGTTTCTTCGG & [37] \\
\hline & $\mathrm{R}:$ & ATGATGGCAACTAACAATAGGGGT & \\
\hline \multirow[t]{2}{*}{ Succinivibrio dextrinosolvens } & $\mathrm{F}:$ & TAGGAGCTTGTGCGATAGTATGG & [29] \\
\hline & $\mathrm{R}:$ & CTCACTATGTCAAGGTCAGGTAAGG & \\
\hline \multirow[t]{2}{*}{ Bacteria general 1} & $\mathrm{~F}:$ & GGATTAGATACCCTGGTAGT & [20] \\
\hline & $\mathrm{R}:$ & CACGACACGAGCTGACG & \\
\hline \multirow[t]{2}{*}{ Bacteria general 2} & F: & GTGSTGCAYGGYTGTCGTCA & [19] \\
\hline & $\mathrm{R}:$ & ACGTCRTCCMCACCTTCCTC & \\
\hline
\end{tabular}

${ }^{\mathrm{a}} F$ forward primer; ${ }^{\mathrm{b}} R$ reverse primer

to cows in the SM group consuming $\sim 3 \mathrm{~kg}$ DM more than those in the CON group specifically after parturition (Fig. 1; $19.6 \mathrm{~kg} / \mathrm{d}$ versus $13.9 \mathrm{~kg} / \mathrm{d}$ ).

\section{Abundance of ruminal bacteria}

The relative abundance of target bacterial species is presented in Table 3. Selenomonas ruminantium was the only bacterial species with an overall treatment effect $(P$ $=0.01$ ) due to a $27.4 \%$ decrease in abundance with SM supplementation. Furthermore, this was the mostabundant bacterial species ranging from $2.63 \times 10^{-1}$ at $-10 \mathrm{~d}(\mathrm{SM})$ to $6.39 \times 10^{-1}$ (a peak in abundance) at $20 \mathrm{~d}$ in cows fed CON.

Concerning day effects, greater relative abundance of Fibrobacter succinogenes $(P<0.01)$ and Succinivibrio dextrinosolvens $(P=0.05)$ was observed at $-10 \mathrm{~d}$ compared with $20 \mathrm{~d}$ postpartum. Furthermore, there was a day effect $(P<0.01)$ for Anaerovibrio lipolytica, Megasphaera elsdenii, Prevotella bryantii, Selenomonas ruminantium and Streptococcus bovis $(P=0.02)$ as these bacterial species had greater abundance at $20 \mathrm{~d}$ compared with $-10 \mathrm{~d}$

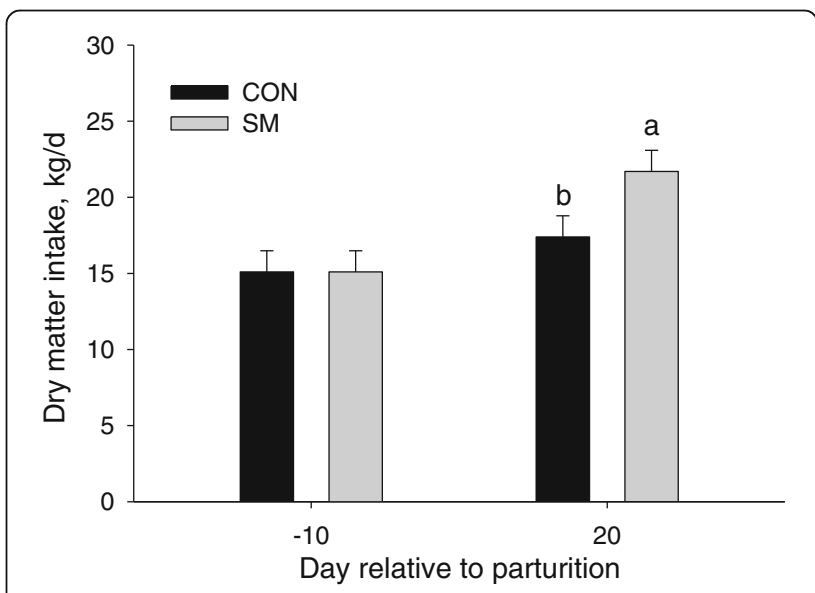

Fig. 1 Dry matter intake in Holstein cows fed a control diet (CON) or CON supplemented with rumen-protected methionine (SM) from d -21 through d 30 relative to parturition. ${ }^{\text {ab }}$ Different letters denote treatment effects $(P<0.05)$ between treatments. The $P$ value for the overall effect of Treatment, Day, and Treatment $\times$ Day was $0.002,0.03$, and 0.48 , respectively. Bars indicate standard error of the means 
Table 3 Relative abundance of microbial species in mixed ruminal fluid from Holstein cows fed a control diet (CON) or CON supplemented with rumen-protected methionine (SM) during the periparturient period

\begin{tabular}{|c|c|c|c|c|c|c|c|c|c|c|c|}
\hline \multirow[b]{3}{*}{ Species } & & & & & \multicolumn{4}{|c|}{ Day $\times$ Treatment } & & & \\
\hline & \multicolumn{2}{|l|}{ Treatment } & \multicolumn{2}{|l|}{ Day } & \multicolumn{2}{|l|}{$\mathrm{CON}$} & \multicolumn{2}{|l|}{ SM } & \multicolumn{3}{|c|}{$P$ value $^{1}$} \\
\hline & $\overline{\mathrm{CON}}$ & SM & -10 & 20 & -10 & 20 & -10 & 20 & $\overline{T r t}$ & Day & $\overline{T \times D}$ \\
\hline A. lipolytica & $3.28 \times 10^{-3}$ & $3.42 \times 10^{-3}$ & $2.50 \times 10^{-3 b}$ & $4.48 \times 10^{-3 a}$ & $2.25 \times 10^{-3}$ & $4.77 \times 10^{-3}$ & $2.77 \times 10^{-3}$ & $4.21 \times 10^{-3}$ & 0.82 & $<0.01$ & 0.42 \\
\hline B. proteoclasticus & $1.07 \times 10^{-2}$ & $8.88 \times 10^{-3}$ & $1.01 \times 10^{-2}$ & $9.46 \times 10^{-3}$ & $1.24 \times 10^{-2}$ & $9.29 \times 10^{-3}$ & $8.18 \times 10^{-3}$ & $9.64 \times 10^{-3}$ & 0.20 & 0.67 & 0.13 \\
\hline E. ruminantium & $2.44 \times 10^{-2}$ & $2.45 \times 10^{-2}$ & $2.23 \times 10^{-2}$ & $2.69 \times 10^{-2}$ & $2.59 \times 10^{-2}$ & $2.31 \times 10^{-2}$ & $1.92 \times 10^{-2}$ & $3.13 \times 10^{-2}$ & 0.98 & 0.38 & 0.16 \\
\hline F. succinogenes & $7.10 \times 10^{-4}$ & $6.93 \times 10^{-4}$ & $1.16 \times 10^{-3 a}$ & $4.25 \times 10^{-4 b}$ & $6.29 \times 10^{-4 B}$ & $8.02 \times 10^{-4 B}$ & $2.13 \times 10^{-3 \mathrm{~A}}$ & $2.25 \times 10^{-4 C}$ & 0.92 & $<0.01$ & $<0.01$ \\
\hline M. elsdenii & $3.90 \times 10^{-5}$ & $1.90 \times 10^{-5}$ & $2.40 \times 10^{-6 b}$ & $2.34 \times 10^{-4 a}$ & $4.60 \times 10^{-6}$ & $2.07 \times 10^{-4}$ & $1.00 \times 10^{-6}$ & $2.65 \times 10^{-4}$ & 0.43 & $<0.01$ & 0.24 \\
\hline P. bryantii & $4.22 \times 10^{-3}$ & $1.30 \times 10^{-3}$ & $7.61 \times 10^{-4 b}$ & $7.20 \times 10^{-3 a}$ & $1.12 \times 10^{-3}$ & $1.60 \times 10^{-2}$ & $5.19 \times 10^{-4}$ & $3.25 \times 10^{-3}$ & 0.12 & $<0.01$ & 0.57 \\
\hline S. ruminantium & $4.10 \times 10^{-1 a}$ & $2.98 \times 10^{-1 b}$ & $2.63 \times 10^{-1 b}$ & $4.65 \times 10^{-1 a}$ & $2.63 \times 10^{-1 C}$ & $6.39 \times 10^{-1 A}$ & $2.63 \times 10^{-1 C}$ & $3.37 \times 10^{-1 B C}$ & 0.01 & $<0.01$ & 0.01 \\
\hline S. amylolytica & $1.02 \times 10^{-4}$ & $2.30 \times 10^{-4}$ & $2.51 \times 10^{-4}$ & $9.40 \times 10^{-5}$ & $9.90 \times 10^{-5 B}$ & $1.05 \times 10^{-4 B}$ & $6.32 \times 10^{-4 A}$ & $8.40 \times 10^{-5 B}$ & 0.16 & 0.07 & 0.05 \\
\hline S. dextrinosolvens & $9.10 \times 10^{-5}$ & $1.60 \times 10^{-4}$ & $1.71 \times 10^{-4 a}$ & $8.50 \times 10^{-5 b}$ & $8.10 \times 10^{-5 B}$ & $1.02 \times 10^{-4 B}$ & $3.64 \times 10^{-4 \mathrm{~A}}$ & $7.00 \times 10^{-5 B}$ & 0.10 & 0.05 & 0.01 \\
\hline S. bovis & $8.09 \times 10^{-3}$ & $3.50 \times 10^{-3}$ & $3.17 \times 10^{-3 b}$ & $8.93 \times 10^{-3 a}$ & $6.68 \times 10^{-3}$ & $9.79 \times 10^{-3}$ & $1.51 \times 10^{-3}$ & $8.14 \times 10^{-3}$ & 0.22 & 0.02 & 0.14 \\
\hline
\end{tabular}

${ }^{1} T r t$ treatment effect, Day day effect, $T \times D$ Treatment by Day interaction

${ }^{\mathrm{ab}}$ Means for overall Treatment or Day effect differ $(P<0.05)$

${ }^{A-C}$ Means for the interaction of Day $\times$ Treatment differ $(P<0.05)$

around parturition. Succinimonas amylolytica tended to be greater $(P=0.07)$ at -10 compared with $20 \mathrm{~d}$.

The relative abundance of Butyrivibrio proteoclasticus and Eubacterium ruminantium was stable $(P>0.05)$ across treatment and time. However, Eubacterium ruminantium was the second most-abundant bacterial species among those studied, ranging from $1.92 \times 10^{-2}$ at $-10 \mathrm{~d}$ with SM to $3.13 \times 10^{-2}$ at $20 \mathrm{~d}$ also with SM.

A Day $\times$ Treatment interaction was observed for Fibrobacter succinogenes, Selenomonas ruminantium, Succinivibrio dextrinosolvens, and $S$. amylolytica. Selenomonas ruminantium abundance nearly doubled $(P=0.01)$ between -10 and $20 \mathrm{~d}$ only in CON cows. In contrast, Fibrobacter succinogenes, Succinimonas amylolytica and Succinivibrio dextrinosolvens decreased on d 20 in SM cows while no change or a decrease was observed in CON cows.

\section{Discussion}

Selenomonas ruminantium was the most abundant bacterial species observed in the present study and agrees with previous classical studies indicating that this Gramnegative bacteria could account for up to $51 \%$ of the total viable bacterial counts within the rumen [22]. The fact that Selenomonas ruminantium was overall $27.4 \%$ lower in response to RPM supplementation could have been associated with the greater DMI in those cows after parturition. This microbial species is a propionateproducer through decarboxylation of succinate, which involves lactic acid production particularly during feeding of higher-concentrate diets [23, 24]. Thus, because the numbers of Selenomonas ruminantium in SM-fed cows actually increased numerically after parturition relative to the prepartum period, it is likely that the greater DMI in those cows either diluted the numbers of this species or increased the diversity of the rumen population.

Availability of propionate for gluconeogenesis by the animal during the transition into lactation relies heavily on both Selenomonas ruminantium and Megasphaera elsdenii numbers in the rumen [25]. Approximately $90 \%$ of glucose in ruminants is supplied by gluconeogenesis, with 50 to $60 \%$ of this being derived from propionate [26]. Thus, the longitudinal change in Selenomonas ruminantium and Megasphaera elsdenii agrees with higher content of rapidly-fermentable carbohydrate in the postpartum diet, i.e. substrate availability likely helped enhance the numbers of these species [23].

Except for Butyrivibrio proteoclasticus (fibrolytic species), the greater numbers of Anaerovibrio lipolytica, Prevotella bryantii, Megasphaera elsdenii, Selenomonas ruminantium, and Streptococcus bovis at d 20 postpartum along with the lower numbers of Fibrobacter succinogenes, Succinimonas amylolytica, and Succinivibrio dextrinosolvens were consistent with a previous study [12]. They attributed these changes to the important features associated with the transition into lactation, e.g. greater concentration of lipid and rapidly-fermentable carbohydrate as a way to provide more energy for the cow during a period when voluntary DMI may be less than optimal.

The fact that abundance of Streptococcus bovis and Prevotella bryantii at $20 \mathrm{~d}$ postpartum was associated with greater abundance of Selenomonas ruminantium and Megasphaera elsdenii seems to indicate some degree of synchronization. These results are broadly consistent with other studies demonstrating that, as dietary grain increases, the prevalence of starch-fermenting bacteria like Streptococcus bovis is increased with a consequent 
synchronized increase in the population ratio of lactateconsuming bacteria like Selenomonas ruminantium and Megasphaera elsdenii to help eliminate lactate via fermentation to propionate [25, 27-29]. Prevotella spp. grows rapidly on starch and produce succinate and propionate as major end-products $[29,30]$. A previous study [12] attributed a higher proportion of Megasphaera elsdenii and Prevotella bryantii after parturition to the higher DMI, which agrees with data in the present study.

The lower abundance of Fibrobacter succinogenes postpartum was associated with greater abundance of Anaerovibrio lipolytica and seems to be partly explained by a potential negative effect of higher availability of dietary unsaturated fatty acids on ruminal cellulolytic bacteria [31]. Indirectly, these results suggest that the greater fiber content of the prepartum diet allowed for greater numbers of Fibrobacter succinogenes, which agrees with a previous study [25]. In ruminants fed high-forage diets Fibrobacter succinogenes is one of the predominant cellulolytic species, favoring the greater production of acetate relative to propionate [32].

The greater abundance of fibrolytic bacteria such as Fibrobacter succinogenes, and starch-degrading bacteria such as Succinimonas amylolytica and Succinivibrio dextrinosolvens at $-10 \mathrm{~d}$ relative to parturition in the SM group was not associated with differences in DMI; however, the lower abundance of these species in response to SM at $20 \mathrm{~d}$ could have been related with the greater DMI in those cows, potentially due to a change in the rumen kinetics such as liquid dilution rate. It is well-established that increases in dietary concentrate/grain to forage not only increase intake but also liquid dilution rate [33]. Thus, besides the greater DMI in cows fed SM, the higher content of corn grain in the postpartum diet (Table 1) might have reduced rumen-retention time of digesta which could partly explain the lower abundance of bacteria. Recent studies demonstrated that RPM can increase DMI both pre and postpartum in dairy cows $[16,34]$. It remains to be determined if the greater DMI and lower relative abundance due to feeding SM would affect digestive enzyme activity within the rumen.

The response of Anaerovibrio lipolytica after parturition confirms its role in the hydrolysis of triacylglycerol into free fatty acids in the rumen [35]. The inverse relationship between Anaerovibrio lipolytica and Fibrobacter succinogenes as it relates to dietary fiber and lipid level was confirmed previously [36]. A previous study [12] also speculated that Anaerovibrio lipolytica (like Megasphaera elsdenii) can use lactate as a substrate for growth during feeding of higher-fermentable diets after parturition. The lack of day, treatment, or interaction effect on the relative abundance of Butyrivibrio proteoclasticus and Eubacterium ruminantium implies that these bacteria might be less sensitive to changes during the transition period.
Clearly, the diets used in the present study appear to have provided enough fermentable energy and nitrogen sources to allow normal growth of the major microbes studied. Whether the rumen microbiome responds to the supply of rumen-protected supplements needs to be explored further. This is particularly important because the actual requirements of methionine (and lysine, for example) during the transition period are unknown.

\section{Conclusions}

In diets with proper balance of rumen-degradable protein and fermentable carbohydrate, the small fraction of Methionine released from the rumen-protected supplement did not seem to compromise growth of major bacterial species in the rumen. In fact, it had a positive effect on 3 major species prepartum when DMI was similar between groups. Because the actual requirements of Methionine (and Lysine, for example) by the cow during the transition period are unknown, it appears warranted to study the rumen microbiome as it relates to supply of rumen-protected amino acids.

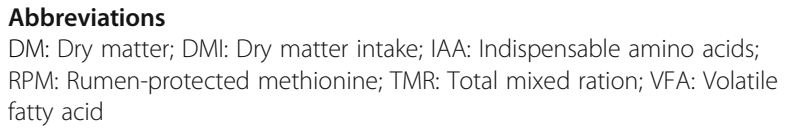

\section{Acknowledgements}

We gratefully acknowledge the help from the staff at the Dairy Research Farm, University of Illinois, Urbana.

\section{Funding}

Not applicable.

\section{Availability of data and materials}

The datasets during and/or analyzed during the current study available from the corresponding authors on reasonable request.

\section{Authors' contributions}

Conceived and designed the experiments: JJL. Performed the analyses: MKA, AAE, ZZ, JCM. Wrote the manuscript: MKA, AAE, VL, JJL. Agree with manuscript results and conclusions: MKA, AAE, ZZ, VL, JCM, JJL. All authors reviewed and approved of the final manuscript.

\section{Ethics approval and consent to participate}

Not applicable.

\section{Consent for publication}

Not applicable.

\section{Competing interests}

The authors declare that they have no competing interests.

\section{Author details}

${ }^{1}$ Department of Animal Sciences, Mammalian NutriPhysioGenomics, University of Illinois, Urbana, IL 61801, USA. ${ }^{2}$ Department of Animal Medicine, Faculty of Veterinary Medicine, Kafrelsheikh University, Kafr El-Shaikh 33516, Egypt. ${ }^{3}$ Department of Animal and Veterinary Sciences, Clemson University, Clemson, SC 29634, USA. ${ }^{4}$ Department of Health Science, Interdepartmental Services Centre of Veterinary for Human and Animal Health, Magna Græcia University of Catanzaro, 88100 Catanzaro, Italy. ${ }^{5}$ Division of Nutritional Sciences, Illinois Informatics Institute, University of Illinois, Urbana, IL, USA. 
Received: 30 June 2017 Accepted: 5 January 2018 Published online: 07 February 2018

\section{References}

1. Jones BA, Mohamed OE, Prange RW, Satter LD. Degradation of methionine hydroxy analog in the rumen of lactating cows. J Dairy Sci. 1988;71:525-9.

2. Clark JH. Lactational responses to Postruminal administration of proteins and amino Acids1. J Dairy Sci. 1975;58:1178-97.

3. Gil LA, Shirley RL, Moore JE. Effect of methionine hydroxy analog on bacterial protein synthesis from urea and glucose, starch or cellulose by rumen microbes, in vitro. J Anim Sci. 1973:37:159-63.

4. Overton TR, LaCount DW, Cicela TM, Clark JH. Evaluation of a ruminally protected methionine product for lactating dairy cows. J Dairy Sci. 1996;79:631-8.

5. Chalupa W. Rumen bypass and protection of proteins and amino acids. J Dairy Sci. 1975:58:1198-218.

6. Lee C, Giallongo F, Hristov AN, Lapierre H, Cassidy TW, Heyler KS, et al. Effect of dietary protein level and rumen-protected amino acid supplementation on amino acid utilization for milk protein in lactating dairy cows. J Dairy Sci. 2015:98:1885-902

7. Li C, Batistel F, Osorio JS, Drackley JK, Luchini D, Loor JJ. Peripartal rumenprotected methionine supplementation to higher energy diets elicits positive effects on blood neutrophil gene networks, performance and liver lipid content in dairy cows. J Anim Sci Biotechnol. 2016;7:18.

8. Osorio JS, Jacometo CB, Zhou Z, Luchini D, Cardoso FC, Loor JJ. Hepatic global DNA and peroxisome proliferator-activated receptor alpha promoter methylation are altered in peripartal dairy cows fed rumen-protected methionine. J Dairy Sci. 2016;99:234-44.

9. Zhou Z, Bulgari O, Vailati-Riboni M, Trevisi E, Ballou MA, Cardoso FC, et al. Rumen-protected methionine compared with rumen-protected choline improves immunometabolic status in dairy cows during the peripartal period. J Dairy Sci. 2016;99:8956-69.

10. Pitta DW, Kumar S, Vecchiarelli B, Shirley DJ, Bittinger K, Baker LD, et al. Temporal dynamics in the ruminal microbiome of dairy cows during the transition period. J Anim Sci. 2014;92:4014-22.

11. Lima FS, Oikonomou G, Lima SF, Bicalho ML, Ganda EK, Filho JC, et al. Prepartum and postpartum rumen fluid microbiomes: characterization and correlation with production traits in dairy cows. Appl Environ Microbiol. 2015;81:1327-37

12. Minuti A, Palladino A, Khan MJ, Alqarni S, Agrawal A, Piccioli-Capelli F, et al. Abundance of ruminal bacteria, epithelial gene expression, and systemic biomarkers of metabolism and inflammation are altered during the peripartal period in dairy cows. J Dairy Sci. 2015;98:8940-51.

13. Firkins JL, YU Z. RUMINANT NUTRITION SYMPOSIUM: How to use data on the rumen microbiome to improve our understanding of ruminant nutrition. J Anim Sci. 2015;93:1450-70.

14. Loor JJ, Elolimy AA, JC MC. Dietary impacts on rumen microbiota in beef and dairy production. Anim Front. 2016;6:22-9.

15. Salsbury RL, Marvil DK, Woodmansee CW, Haenlein GFW. Utilization of Methionine and Methionine Hydroxy analog by rumen microorganisms in vitro. J Dairy Sci. 1971;54:390-6.

16. Zhou Z, Vailati-Riboni M, Trevisi E, Drackley JK, Luchini DN, Loor JJ. Better postpartal performance in dairy cows supplemented with rumen-protected methionine compared with choline during the peripartal period. J Dairy Sci. 2016:99:8716-32.

17. Osorio JS, Ji P, Drackley JK, Luchini D, Loor JJ. Supplemental Smartamine M or MetaSmart during the transition period benefits postpartal cow performance and blood neutrophil function. J Dairy Sci. 2013;96:6248-63.

18. Yu Z, Morrison M. Improved extraction of PCR-quality community DNA from digesta and fecal samples. BioTechniques. 2004;36:808-12.

19. Maeda H, Fujimoto C, Haruki Y, Maeda T, Kokeguchi S, Petelin M, et al. Quantitative real-time PCR using TaqMan and SYBR green for Actinobacillus actinomycetemcomitans, Porphyromonas gingivalis, Prevotella intermedia, tetQ gene and total bacteria. FEMS Immunol Med Microbiol. 2003:39:81-6.

20. Fliegerova K, Tapio I, Bonin A, Mrazek J, Callegari ML, Bani P, et al. Effect of DNA extraction and sample preservation method on rumen bacterial population. Anaerobe. 2014:29:80-4

21. Ramirez-Farias C, Slezak K, Fuller Z, Duncan A, Holtrop G, Louis P. Effect of inulin on the human gut microbiota: stimulation of Bifidobacterium adolescentis and Faecalibacterium prausnitzii. Br J Nutr. 2009;101:541-50.

22. Caldwell DRBM. Medium without rumen fluid for non- selective enumeration and isolation of rumen bacteria. Appl Environ Microbiol. 1966;14:794-801.
23. Fernando SC, Purvis HT 2nd, Najar FZ, Sukharnikov LO, Krehbiel CR, Nagaraja

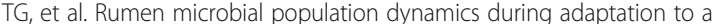
high-grain diet. Appl Environ Microbiol. 2010;76:7482-90.

24. Stewart CS, Flynt HJ, Bryant MP. The rumen bacteria. In: Stewart PNHaCS, editor. The rumen microbial ecosystem. New York: Blackie Academic and Professional; 1997. p. 10-72.

25. Wang X, Li X, Zhao C, Hu P, Chen H, Liu Z, et al. Correlation between composition of the bacterial community and concentration of volatile fatty acids in the rumen during the transition period and ketosis in dairy cows. Appl Environ Microbiol. 2012;78:2386-92.

26. Reynolds CK, Huntington GB, Tyrrell HF, Reynolds PJ. Net metabolism of volatile fatty acids, D-beta-hydroxybutyrate, nonesterifield fatty acids, and blood gasses by portal-drained viscera and liver of lactating Holstein cows. J Dairy Sci. 1988;71:2395-405.

27. Russell JB, Cotta MA, Dombrowski DB. Rumen bacterial competition in continuous culture: Streptococcus Bovis versus Megasphaera elsdenii. Appl Environ Microbiol. 1981;41:1394-9.

28. Russell JR, Hino T. Regulation of lactate production in Streptococcus Bovis: a spiraling effect that contributes to rumen acidosis. J Dairy Sci. 1985;68:1712-21.

29. Khafipour E, Li S, Plaizier JC, Krause DO. Rumen microbiome composition determined using two nutritional models of subacute ruminal acidosis. Appl Environ Microbiol. 2009:75:7115-24.

30. Rodríguez F. Control of lactate accumulation in ruminants using Prevotella bryantii. PhD thesis lowa State University, Ames. 2003.

31. Yang SL, Bu DP, Wang JQ, Hu ZY, Li D, Wei HY, et al. Soybean oil and linseed oil supplementation affect profiles of ruminal microorganisms in dairy cows. Animal. 2009;3:1562-9.

32. Chen JWP. Competition among three predominant ruminal cellulolytic bacteria in the absence or presence of non-cellulolytic bacteria. Microbiology. 2001;147:21-30.

33. Stokes MR, Bull LS, Halteman WA. Rumen liquid dilution rate in dairy cows fed once daily: effects of diet and sodium bicarbonate supplementation. $J$ Dairy Sci. 1985:68:1171-80.

34. Batistel F, Arroyo JM, Bellingeri A, Wang L, Saremi B, Parys C, et al. Ethyl-cellulose rumen-protected methionine enhances performance during the periparturient period and early lactation in Holstein dairy cows. J Dairy Sci. 2017;100:7455-7467.

35. Harfoot CGH, G. P.: Lipid metabolism in the rumen.. In: The Rumen Microbial Ecosystem. Edited by P. N. Hobson DSS, vol. 2nd ed. London, UK: Chapman and Hall; 1997;382-426.

36. Liu SJ, Bu DP, Wang JQ, Liu L, Liang S, Wei HY, et al. Effect of incremental levels of fish oil supplementation on specific bacterial populations in bovine ruminal fluid. J Anim Physiol Anim Nutr (Berl). 2012:96:9-16.

37. Stevenson DM, Weimer PJ. Dominance of Prevotella and low abundance of classical ruminal bacterial species in the bovine rumen revealed by relative quantification real-time PCR. Appl Microbiol Biotechnol. 2007;75:165-74.

\section{Submit your next manuscript to BioMed Central and we will help you at every step:}

- We accept pre-submission inquiries

- Our selector tool helps you to find the most relevant journal

- We provide round the clock customer support

- Convenient online submission

- Thorough peer review

- Inclusion in PubMed and all major indexing services

- Maximum visibility for your research

Submit your manuscript at www.biomedcentral.com/submit
) Biomed Central 